\title{
Selectively light-up detection of phosgene with an aggregation-induced emission based fluorescent sensor
}

\author{
Ke Cheng, ${ }^{\dagger}$ Ningwen Yang, ${ }^{\dagger}$ Qiu-Yan Li,${ }^{\dagger}$ Xue-Wang Gao, ${ }^{*},+$ and Xiao-Jun Wang, ${ }^{*}$, \\ †Jiangsu Key Laboratory of Green Synthetic Chemistry for Functional Materials, School of Chemistry and \\ Materials Science, Jiangsu Normal University, Xuzhou 221116, P. R. China. \\ ${ }^{\ddagger}$ Key Laboratory of Photochemical Conversion and Optoelectronic Materials, Technical Institute of Physics and \\ Chemistry, Chinese Academy of Sciences, Beijing 100190, P. R. China \\ E-mail: xjwang@jsnu.edu.cn (X.-J. Wang) \\ gaoxuewang@mail.ipc.ac.cn (X.-W. Gao)
}




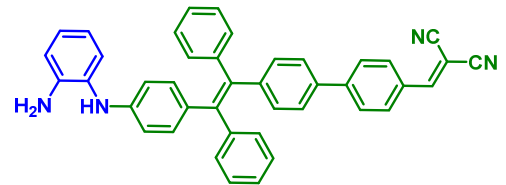

OPD-TPE-Py-2CN

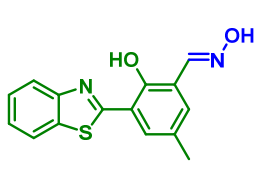

HBT-phos<smiles>O=C(O)C=Cc1ccc(O)cc1</smiles>

DCA<smiles>CCN(CC)c1ccc2c(c1)Oc1cc(N(CC)CC)ccc1C(C)(C)C2</smiles>

dRB-EDA

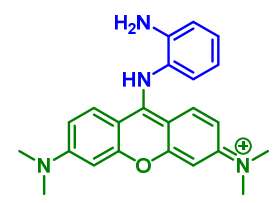

PY-OPD<smiles>[CH]N(Cc1ccc(C(=O)NCCN)cc1)c1cc(=O)oc2c(C)cc(C)cc12</smiles>

1 Donor + Acceptor

2

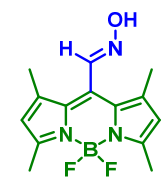

1-oxime
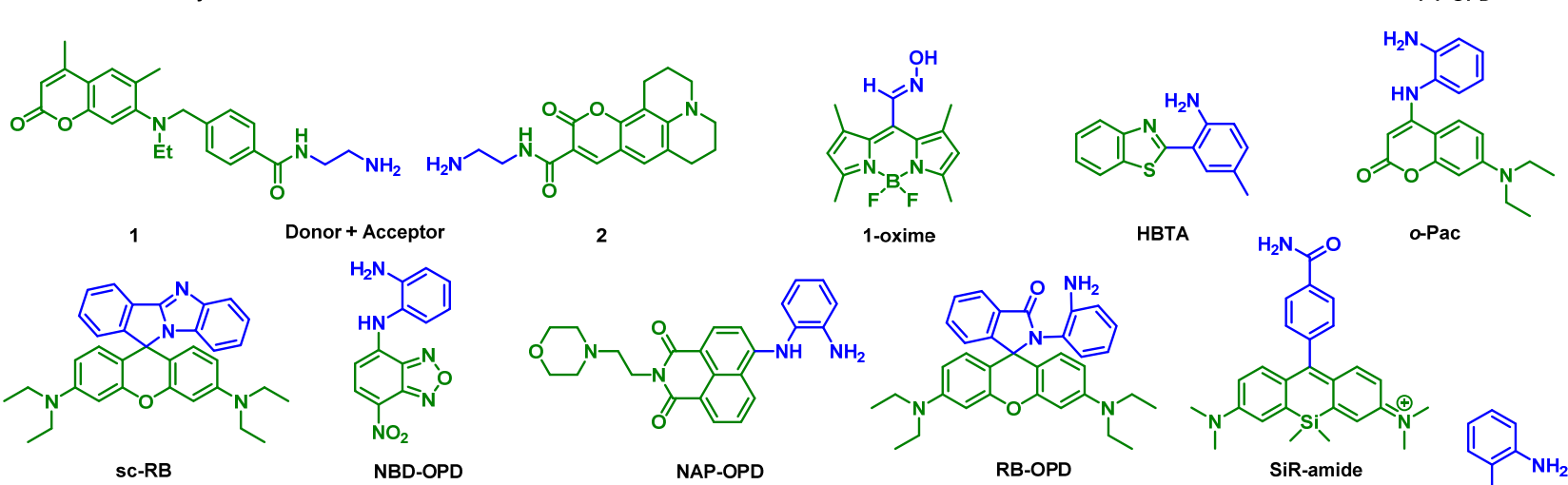

NAP-OPD
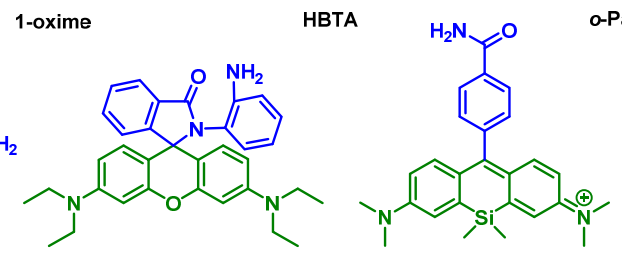

RB-OPD

SiR-amide

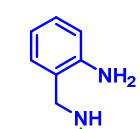

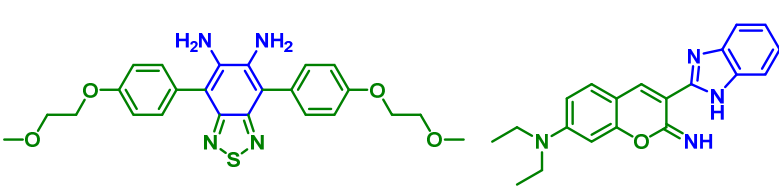

BTA

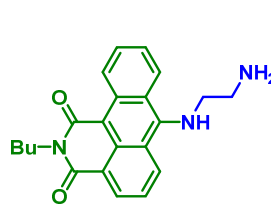

AC-6ED

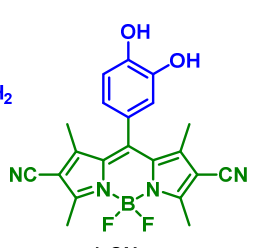

1-CN

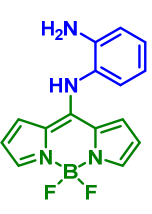

o-Pab

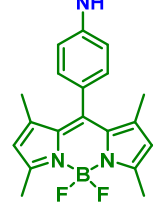
BOD-SYR

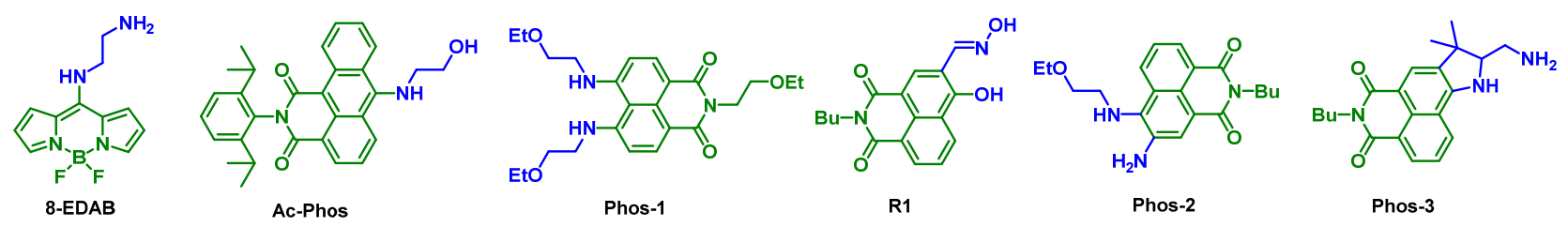

Scheme S1. Chemical structures of recently reported fluorescent probes for phosgene detection. 
Table S1. Comparison of fluorescent probes for phosgene detection.

\begin{tabular}{|c|c|c|c|c|c|}
\hline Probes and References & Fluorophore & $\begin{array}{l}\text { Mechanism and } \\
\text { working mode }\end{array}$ & $\begin{array}{l}\text { Detection } \\
\text { limit in } \\
\text { solution }\end{array}$ & $\begin{array}{c}\text { Detection limit } \\
\text { in } \\
\text { gas phase }\end{array}$ & $\begin{array}{l}\text { AIE of } \\
\text { product }\end{array}$ \\
\hline DATPE, this work & TPE & ICT, turn-on & $21 \mathrm{nM}$ & $0.1 \mathrm{ppm}$ & Yes \\
\hline OPD-TPE-Py-2CN ${ }^{[\mathrm{S1}]}$ & TPE & ICT, ratiometric & $19 \mu \mathrm{M}$ & $1.87 \mathrm{ppm}$ & Yes \\
\hline HBT-phos ${ }^{[22]}$ & HBT & ESIPT, turn-on & $0.48 \mathrm{nM}$ & $0.34 \mathrm{ppm}$ & Yes \\
\hline $\mathrm{DCA}^{[\mathrm{S3}]}$ & coumarin & $\begin{array}{c}\text { Intramolecular } \\
\text { cyclization, turn-on }\end{array}$ & $1 \mathrm{nM}$ & - & No \\
\hline $\mathrm{dRB}^{-E D A}{ }^{[\mathrm{S} 4]}$ & Rhodamine & $\begin{array}{l}\text { opening of the } \\
\text { spiro-(deoxy)lactam, } \\
\text { turn-on }\end{array}$ & $50 \mathrm{nM}$ & $\begin{array}{c}0.8 \mathrm{mg} / \mathrm{L} \\
(\sim 200 \mathrm{ppm})\end{array}$ & No \\
\hline $\mathrm{PY}-\mathrm{OPD}^{[\mathrm{S} 5]}$ & pyronins & PET, turn-on & $20 \mathrm{nM}$ & $0-20 \mathrm{ppm}$ & No \\
\hline Donor 1+ Acceptor $2^{[\mathrm{S} 6]}$ & coumarins & FRET, ratiometric & $50 \mu \mathrm{M}$ & - & No \\
\hline 1 -oxime ${ }^{[\mathrm{S} 7]}$ & BODIPY & $\begin{array}{l}\text { dehydration of oxime, } \\
\text { turn-on }\end{array}$ & $0.93 \mathrm{ppm}$ & $0.1 \mathrm{ppm}$ & No \\
\hline $\mathrm{HBTA}^{[\mathrm{S} 8]}$ & HBT & ESIPT, ratiometric & $1.4 \mu \mathrm{M}$ & $\begin{array}{c}0.8 \mathrm{mg} / \mathrm{L} \\
(\sim 184 \mathrm{ppm})\end{array}$ & No \\
\hline$o-\mathrm{Pac}^{[\mathrm{S} 9]}$ & coumarin & PET, turn-on & $3 \mathrm{nM}$ & $10 \mathrm{ppm}$ & No \\
\hline $\mathrm{sc}-\mathrm{RB}^{[\mathrm{S} 10]}$ & Rhodamine & $\begin{array}{l}\text { spirocyclic ring-open } \\
\text { reaction, turn-on }\end{array}$ & $32 \mathrm{nM}$ & - & No \\
\hline $\mathrm{NBD}^{-O P D}{ }^{[\mathrm{S} 11]}$ & $\begin{array}{c}\text { nitrobenzo[c] }][1,2,5] \text { oxadi } \\
\text { azole }\end{array}$ & PET, turn-on & $7 \mathrm{nM}$ & - & No \\
\hline NAP-OPD $^{[\mathrm{S} 11]}$ & naphthalimide & ICT, turn-on & $28 \mathrm{nM}$ & $\begin{array}{c}0.8 \mathrm{mg} / \mathrm{L} \\
(\sim 184 \mathrm{ppm})\end{array}$ & No \\
\hline $\mathrm{RB}^{-O P D}{ }^{[\mathrm{S} 11]}$ & Rhodamine & ring-opening, turn-on & $28 \mathrm{nM}$ & - & No \\
\hline SiR-amide ${ }^{[\mathrm{S} 12]}$ & Si-rhodamine & $\begin{array}{l}\text { amide to nitrile, } \\
\text { turn-on }\end{array}$ & $8.9 \mathrm{nM}$ & $\begin{array}{l}0.1 \mathrm{mg} / \mathrm{L} \\
(\sim 23 \mathrm{ppm})\end{array}$ & No \\
\hline $\mathrm{BTA}^{[\mathrm{S} 13]}$ & benzothiadiazole & ICT, turn-on & $20 \mathrm{nM}$ & $10 \mathrm{ppm}$ & No \\
\hline IC-phos $^{[\mathrm{S} 14]}$ & $\begin{array}{l}\text { 3-benzimidazole } \\
\text { iminocoumarin }\end{array}$ & ICT, ratiometric & $27 \mathrm{nM}$ & $\begin{array}{l}0.1 \mathrm{mg} / \mathrm{L} \\
(\sim 23 \mathrm{ppm})\end{array}$ & No \\
\hline $\mathrm{AC}-6 \mathrm{ED}^{[\mathrm{S} 15]}$ & anthracene carboximide & ICT, ratiometric & $0.09 \mathrm{nM}$ & $0.1 \mathrm{ppm}$ & No \\
\hline $1-\mathrm{CN}^{[\mathrm{S} 16]}$ & BODIPY & PET, turn-on & $8 \mathrm{pM}$ & $0.5 \mathrm{ppm}$ & No \\
\hline BOD-SYR ${ }^{[\mathrm{S} 17]}$ & BODIPY & PET, turn-on & $179 \mathrm{nM}$ & $50 \mathrm{ppm}$ & No \\
\hline$o-\mathrm{Pab}^{[\mathrm{S} 18]}$ & BODIPY & PET, turn-on & $2.7 \mathrm{nM}$ & $20 \mathrm{ppm}$ & No \\
\hline $8-\mathrm{EDAB}^{[\mathrm{S} 19]}$ & BODIPY & ICT, turn-on & $0.12 \mathrm{nM}$ & $0.5 \mathrm{ppm}$ & No \\
\hline Ac-Phos ${ }^{[\mathrm{S} 20]}$ & anthracene carboximide & ICT, ratiometric & $2.3 \mathrm{nM}$ & $20 \mathrm{ppm}$ & No \\
\hline Phos- $1^{[\mathrm{S} 21]}$ & 4,5-diaminonaphthalimide & ICT, ratiometric & $1.3 \mathrm{nM}$ & $\begin{array}{c}1 \mathrm{mg} / \mathrm{L} \\
(\sim 230 \mathrm{ppm})\end{array}$ & No \\
\hline $\mathrm{R} 1^{[\mathrm{S} 22]}$ & naphthalimide & ESIPT, ratiometric & $0.09 \mathrm{nM}$ & $0.5 \mathrm{ppm}$ & No \\
\hline Phos- $2^{[\mathrm{S} 23]}$ & naphthalimide & ICT, turn-on & $0.6 \mathrm{nM}$ & $2.5 \mathrm{ppm}$ & No \\
\hline Phos-3 $3^{[\mathrm{S} 24]}$ & naphthalimide & ICT, ratiometric & $0.3 \mathrm{nM}$ & $10 \mathrm{ppm}$ & No \\
\hline
\end{tabular}




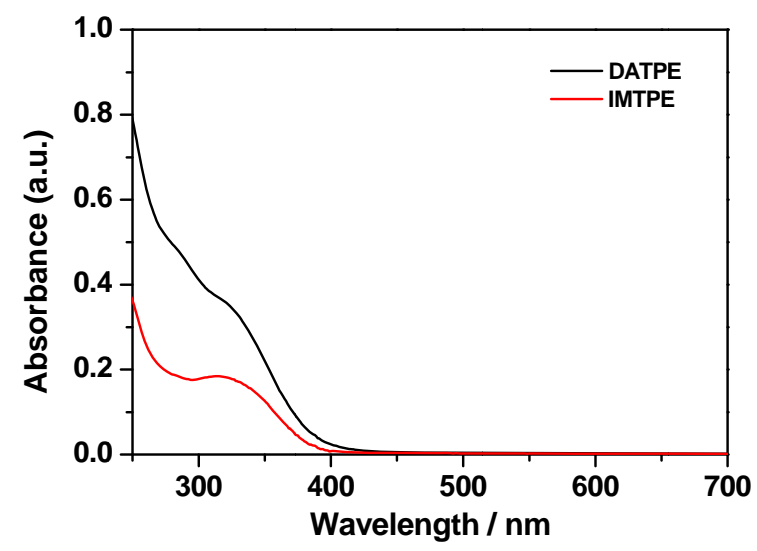

Figure S1. UV-vis absorption spectra of DATPE and IMTPE $(10 \mu \mathrm{M})$ in THF at room temperature.
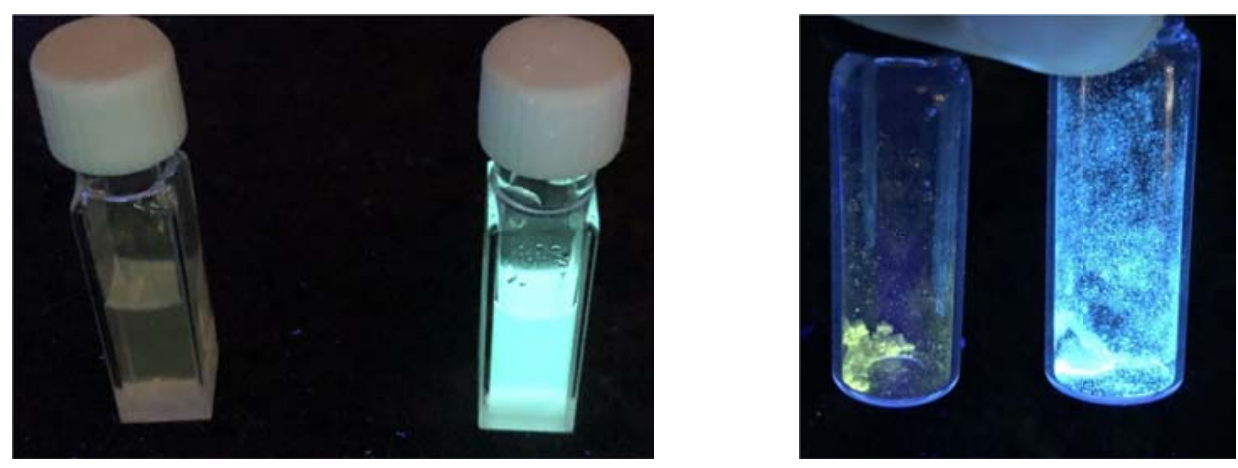

\begin{tabular}{cccc}
\hline$\Phi_{\mathrm{F}}$ & in pure THF & in $f_{\mathrm{w}}=95 \% \mathrm{H}_{2} \mathrm{O}-\mathrm{THF}$ & in solid state \\
\hline DATPE & n.d. & $3 \%$ & $5 \%$ \\
\hline IMTPE & n.d. & $56 \%$ & $78 \%$ \\
\hline
\end{tabular}

Fluorescence quantum yield $\Phi_{\mathrm{F}}$ determined using 9,10 -diphenylanthracene ( $\Phi_{\mathrm{F}}=90 \%$ in cyclohexane) as standard (for solution sample) or measured by a calibrated integrating sphere (for solid sample); n.d. = not determined because of the weak PL signals.

Figure S2. Fluorescence photos of DATPE and IMTPE in in $\mathrm{H}_{2} \mathrm{O}-\mathrm{THF}$ solution $\left(f_{\mathrm{w}}=95 \%\right.$, left $)$ and in solid state (right) under a UV $365 \mathrm{~nm}$ lamp. 

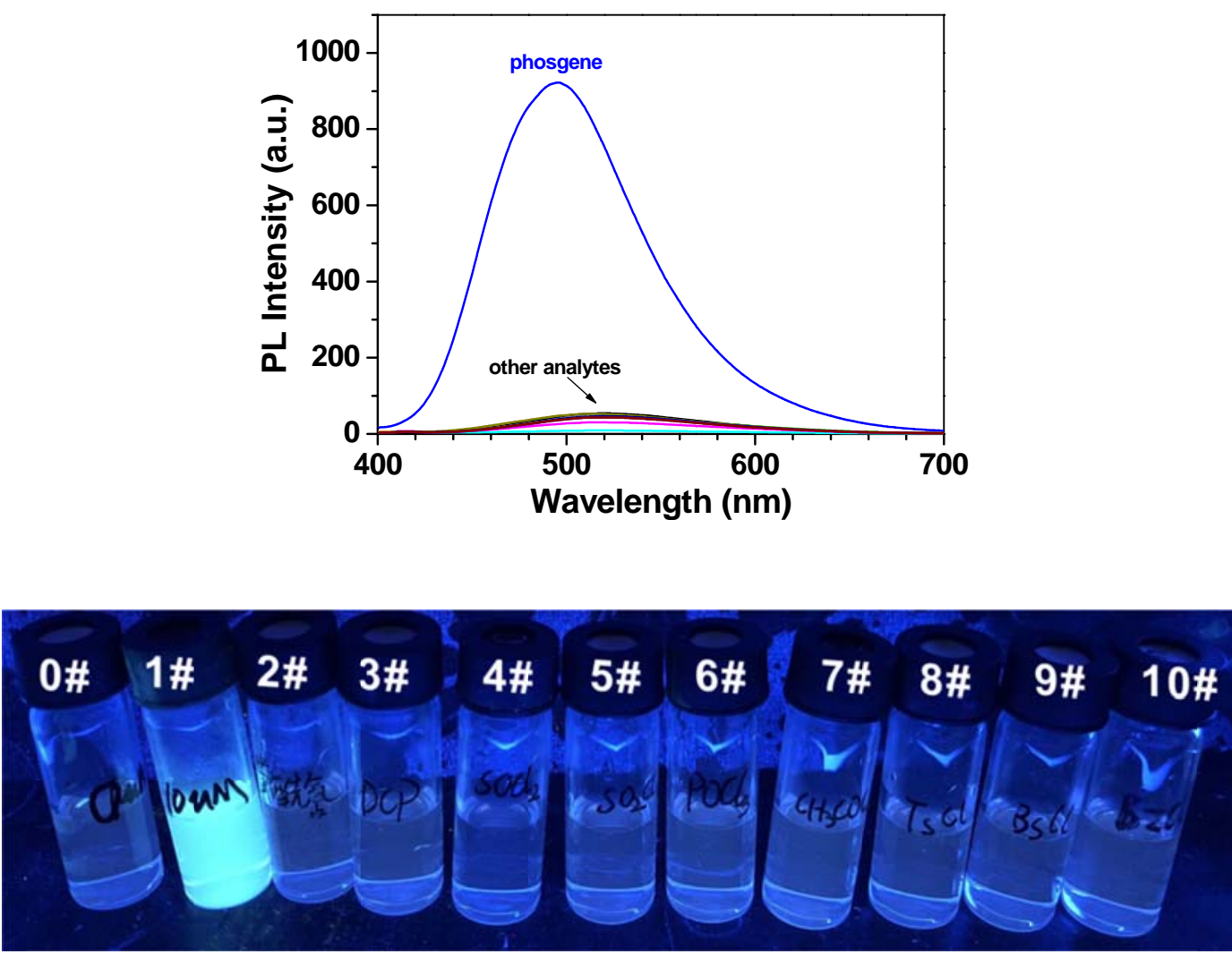

Figure S3. PL spectra of $10 \mu \mathrm{M}$ DATPE in $\mathrm{H}_{2} \mathrm{O}$-THF solution $\left(f_{\mathrm{w}}=95 \%\right)$ after addition of triphosgene/TEA (10 $\mu \mathrm{M})$ and other analytes $(20 \mu \mathrm{M})$ and the corresponding fluorescence photos under $365 \mathrm{~nm}$ light. 0 , blank; 1, phosgene; 2 , oxalyl chloride; 3 , diethyl chlorophosphate (DCP); $4, \mathrm{SOCl}_{2} ; 5, \mathrm{SO}_{2} \mathrm{Cl}_{2} ; 6, \mathrm{POCl}_{3} ; 7$, acetyl chloride; 8, tosyl chloride ( $\mathrm{TsCl}) ; 9$, benzenesulfonyl chloride ( $\mathrm{BsCl})$; 10, benzoyl chloride $(\mathrm{BzCl})$. 


\section{Details of Assay Experiments}

Preparation of phosgene: As a toxic gas, phosgene is danger to use directly. We employed triphosgene, which is a common nonvolatile and less toxic precursor, to produce three phosgene molecules in the presence of tertiary amine in solution. Dichloromethane as the solvent was used all measurements in solutions. In this research, phosgene can be produced in situ in DATPE solution containing triethylamine (TEA) upon addition of triphosgene.

Preparation of the Test Paper: Polystyrene ( $2 \mathrm{~g}$ ) was dissolved in $50 \mathrm{~mL}$ DCM to obtain a sticky homogenous solution and then DATPE ( $2 \mathrm{mg}$ ) was added. A filter paper was cut into strips, and then tied with copper wire. Then, the paper was immersed in the solution and then taken out immediately to dry in air. Finally, the test paper with DATPE was made simply to detect phosgene and other analytes in the gas phase.

\section{Detection of phosgene in the gas phase:}

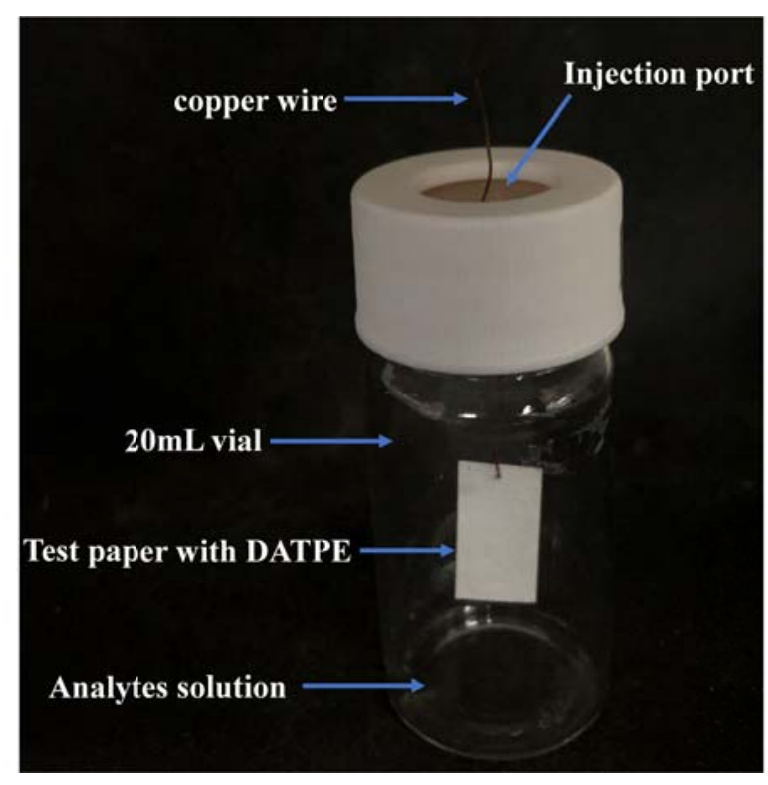

Figure S4. Schematic diagram of detection device of phosgene and other analytes vapor. 
Detection of phosgene gas in various concentrations: Four concentrations of triphosgene stock solutions in DCM were prepared: $0.2 \mathrm{~g} \mathrm{~L}^{-1}, 1 \mathrm{~g} \mathrm{~L}^{-1}, 2 \mathrm{~g} \mathrm{~L}^{-1}$ and $10 \mathrm{~g} \mathrm{~L}^{-1}$. Using a microliter syringes, $10 \mu \mathrm{L}$ above solutions were injected into $20 \mathrm{~mL}$ detection devices, and followed by the supplementary addition of $5 \mu \mathrm{L}$ DCM containing $0.1 \% \mathrm{v} / \mathrm{v}$ TEA. Assuming complete vaporization of the solution, the concentrations of phosgene gas in air were estimated to be $0.1,0.5,1$ and $5 \mathrm{ppm}$, respectively. After $1 \mathrm{~min}$, the fluorescence of these test papers was taken pictures under $365 \mathrm{~nm}$ light.

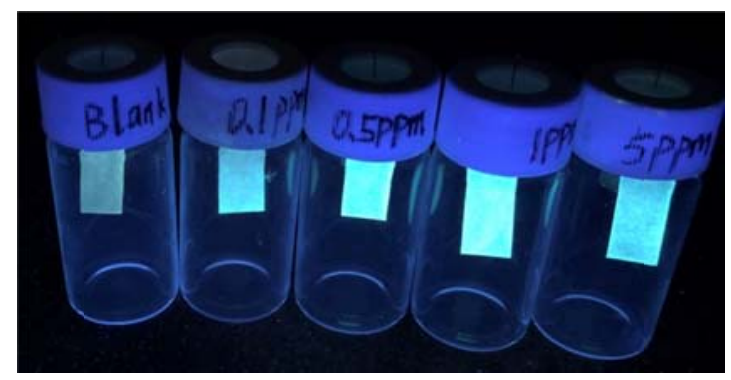

Figure S5. Fluorescence photo of DATPE test papers upon the exposure to various amount of phosgene (0-5 ppm).

\section{Selective detection of phosgene over other analytes vapor.}

The concentration $\left(40 \mathrm{mg} / \mathrm{mL}\right.$ ) of DCP, $\mathrm{SOCl}_{2}, \mathrm{SO}_{2} \mathrm{Cl}_{2}, \mathrm{POCl}_{3}, \mathrm{CH}_{3} \mathrm{COCl}$, TsCl, $\mathrm{BsCl}$ and $\mathrm{BzCl}$ were prepared in DCM. Using a microliter syringes, $10 \mu \mathrm{L}$ above solutions were injected to $20 \mathrm{~mL}$ detection devices $(20 \mathrm{ppm})$, respectively. After $1 \mathrm{~min}$, the fluorescence of these test papers were taken pictures under $365 \mathrm{~nm}$ light.

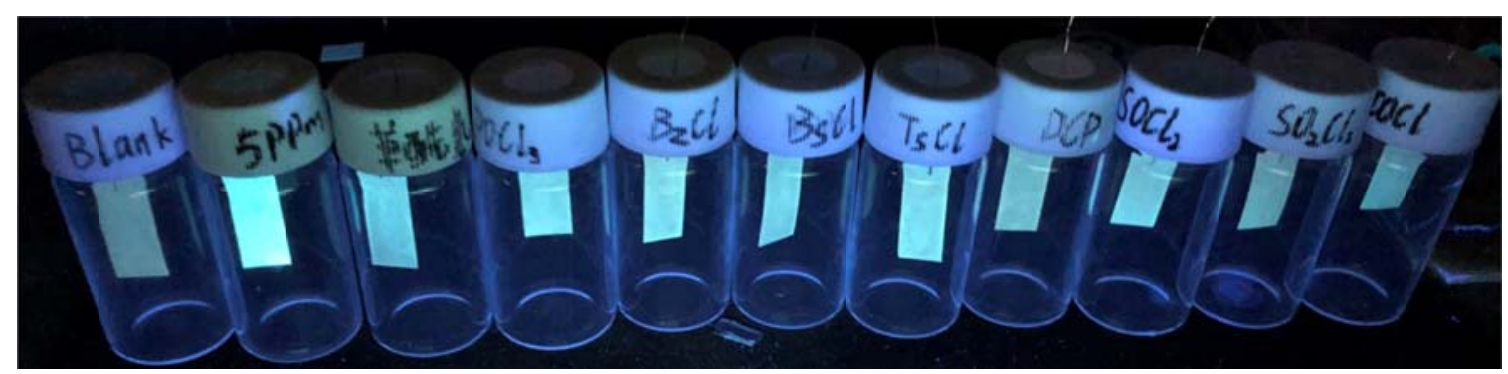

Figure S6. Fluorescence responses of DATPE-based test papers upon exposure to phosgene vapor (5 ppm) and various other analytes vapor (20 ppm) : 0 , blank; 1 , phosgene, 5 ppm; 2 , oxalyl chloride; $3, \mathrm{POCl}_{3} ; 4, \mathrm{BzCl} ; 5, \mathrm{BsCl}$; 6, TsCl; 7, DCP; $8, \mathrm{SOCl}_{2} ; 9, \mathrm{SO}_{2} \mathrm{Cl}_{2} ; 10, \mathrm{CH}_{3} \mathrm{COCl}$ in vials $(20 \mathrm{~mL})$ for 1 min under the irradiation of UV lamp $(365 \mathrm{~nm})$. 


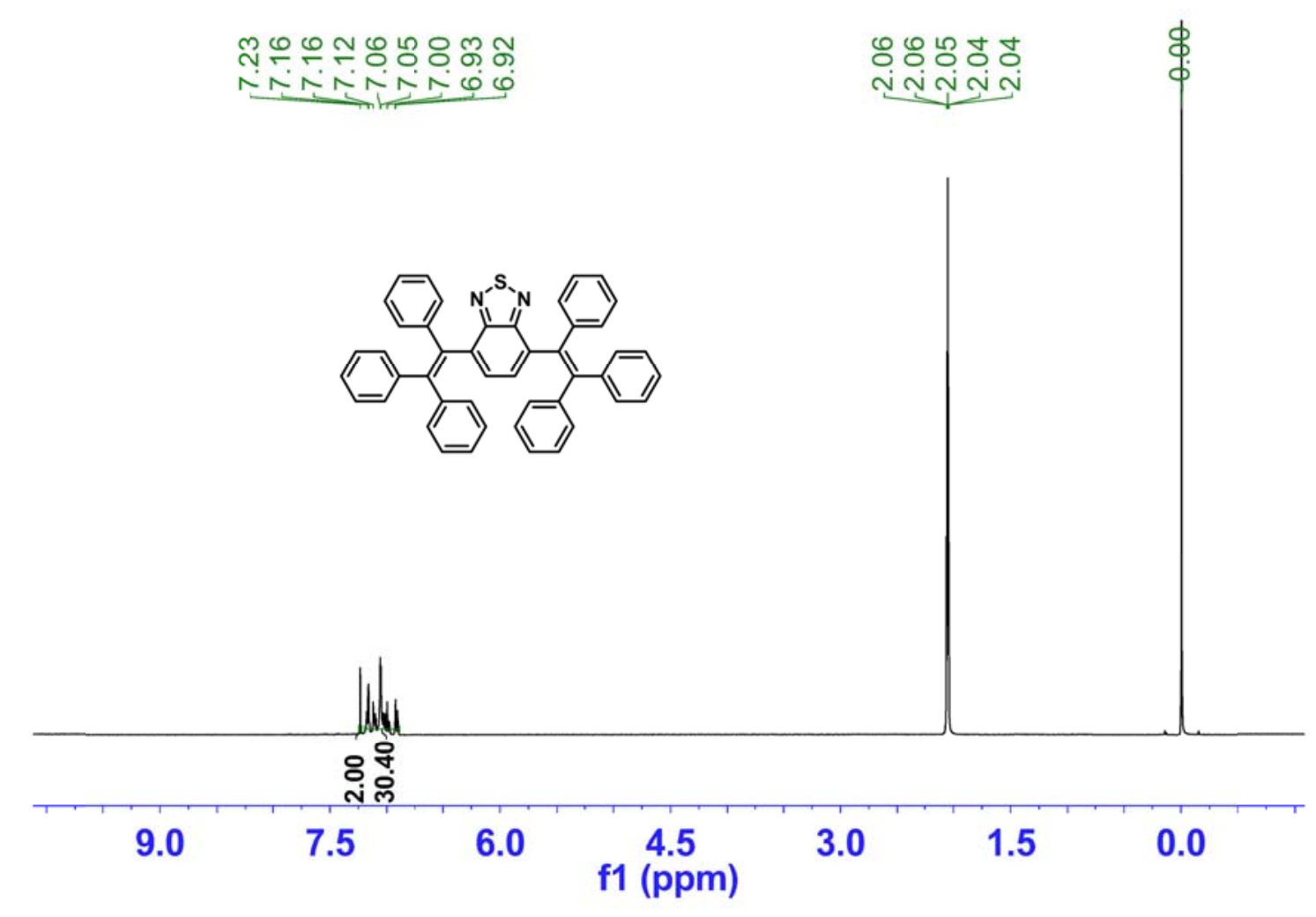

Figure S7. ${ }^{1} \mathrm{H}$ NMR spectra of compound 3 ( $d_{6}$-acetone, $\left.400 \mathrm{MHz}\right)$.

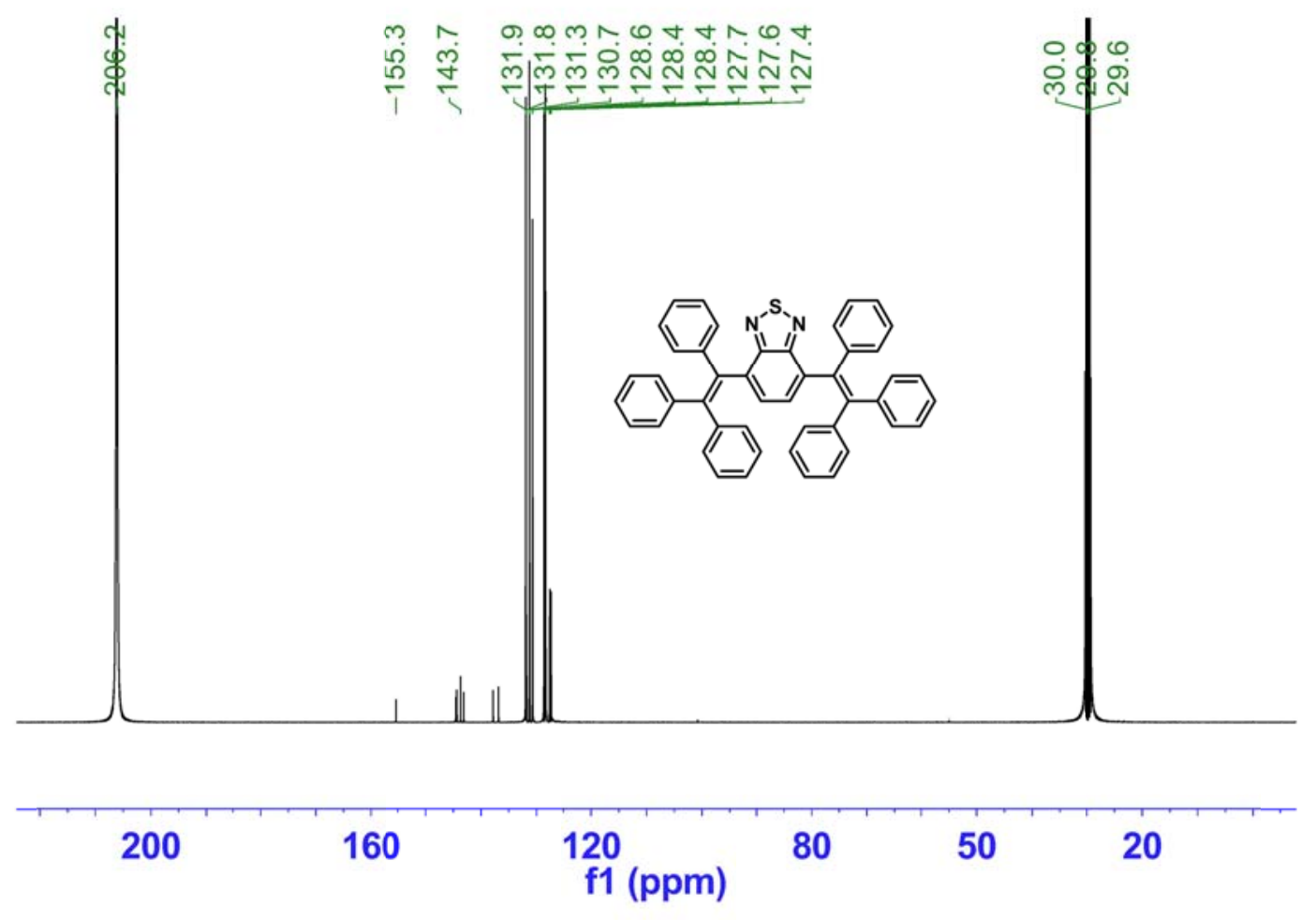

Figure S8. ${ }^{13} \mathrm{C}$ NMR spectra of compound $3\left(d_{6}\right.$-acetone, $\left.101 \mathrm{MHz}\right)$. 

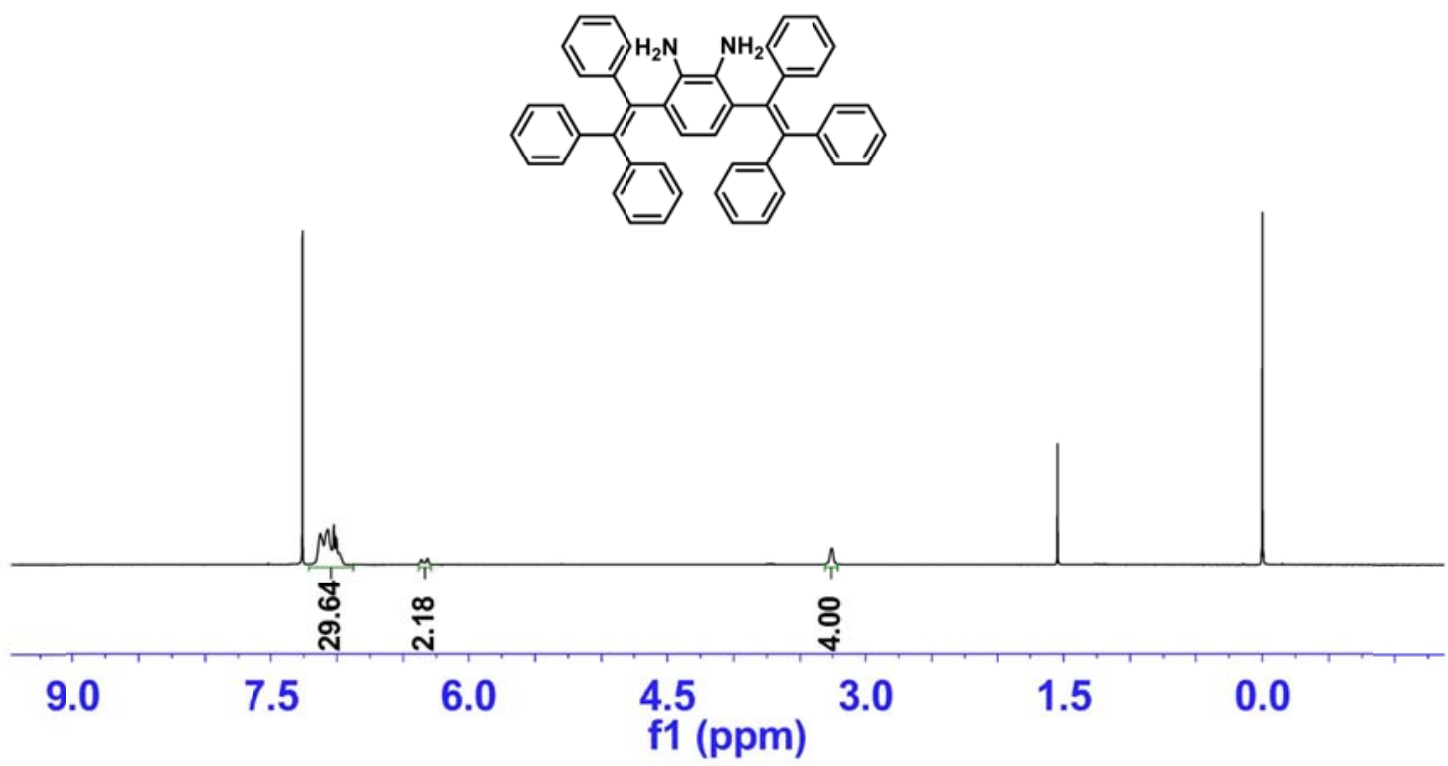

Figure S9. ${ }^{1} \mathrm{H}$ NMR spectra of compound DATPE $\left(\mathrm{CDCl}_{3}, 400 \mathrm{MHz}\right)$.
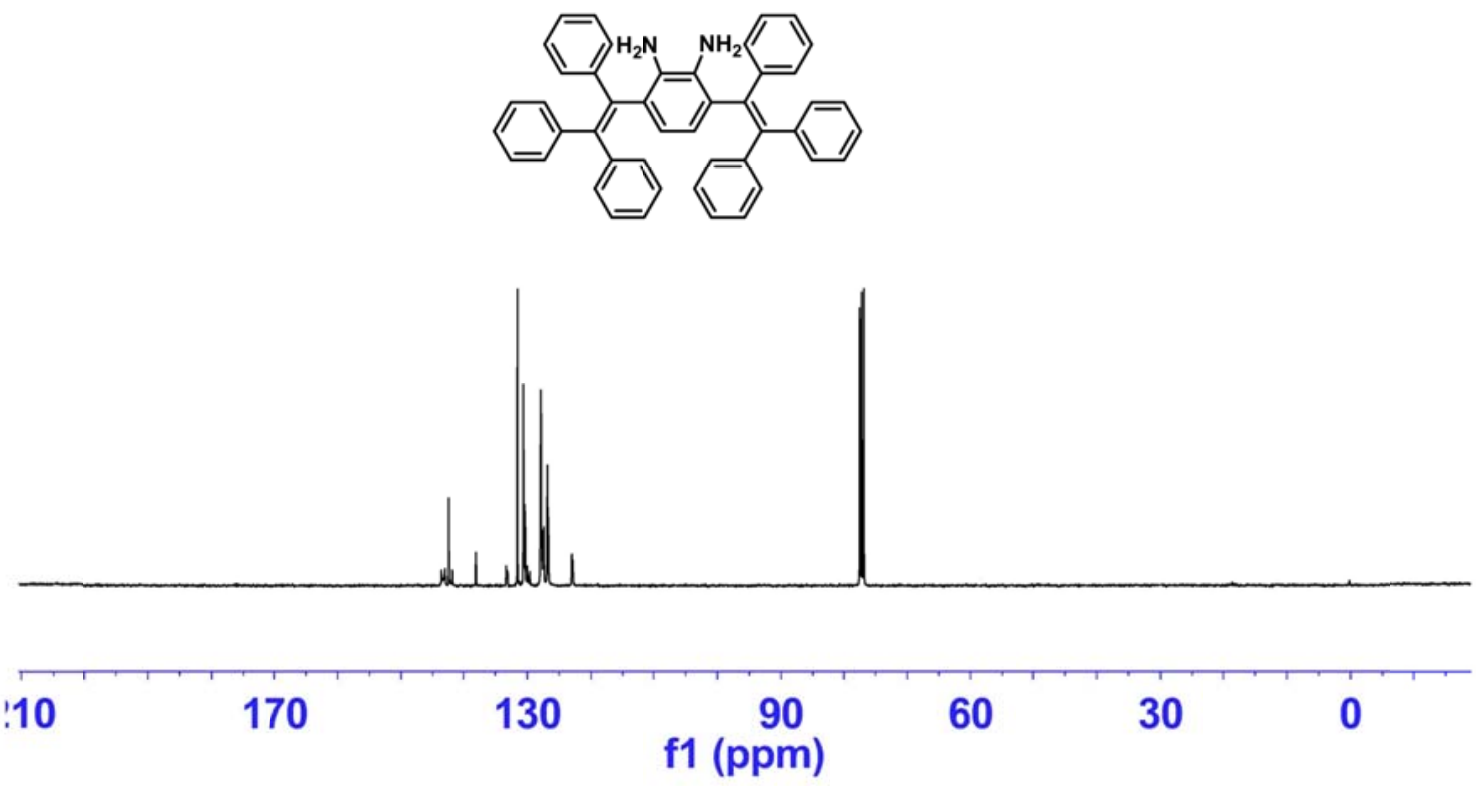

Figure S10. ${ }^{13} \mathrm{C}$ NMR spectra of compound DATPE $\left(\mathrm{CDCl}_{3}, 101 \mathrm{MHz}\right)$. 


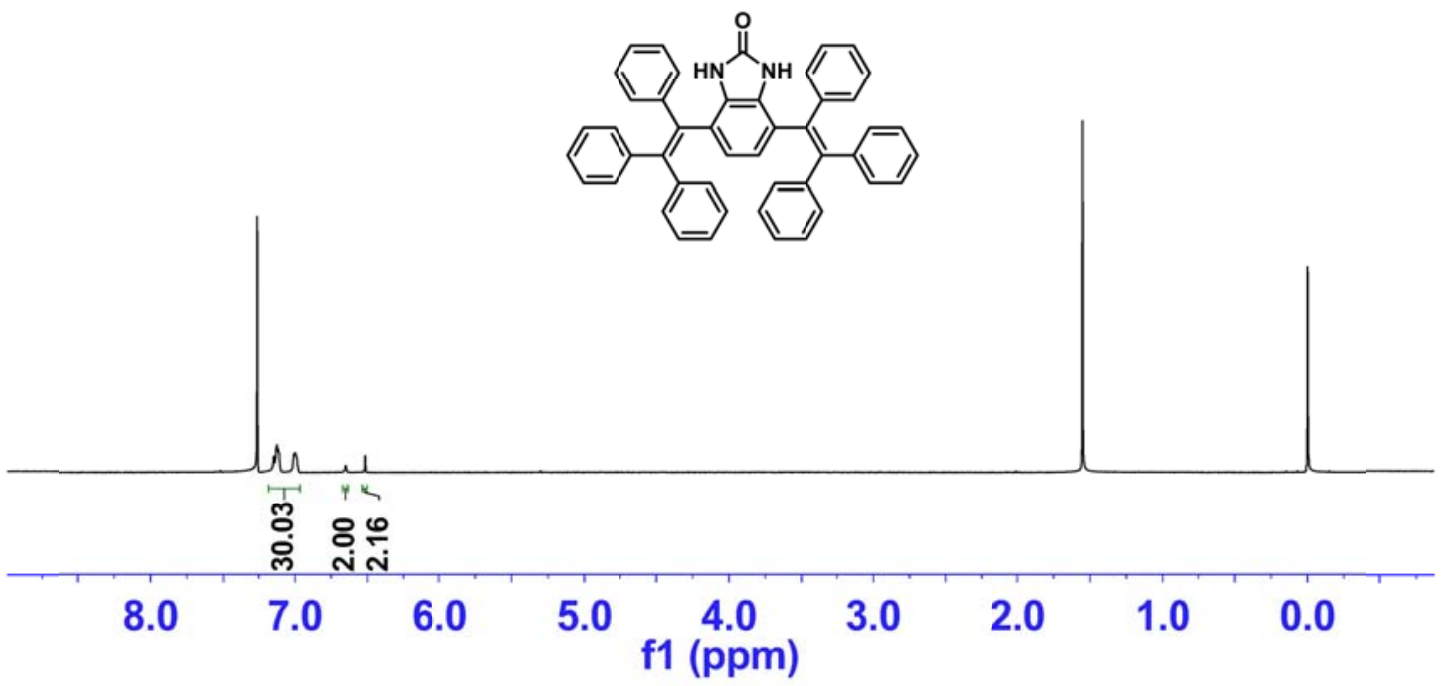

Figure S11. ${ }^{1} \mathrm{H}$ NMR spectra of compound IMTPE $\left(\mathrm{CDCl}_{3}, 400 \mathrm{MHz}\right)$.
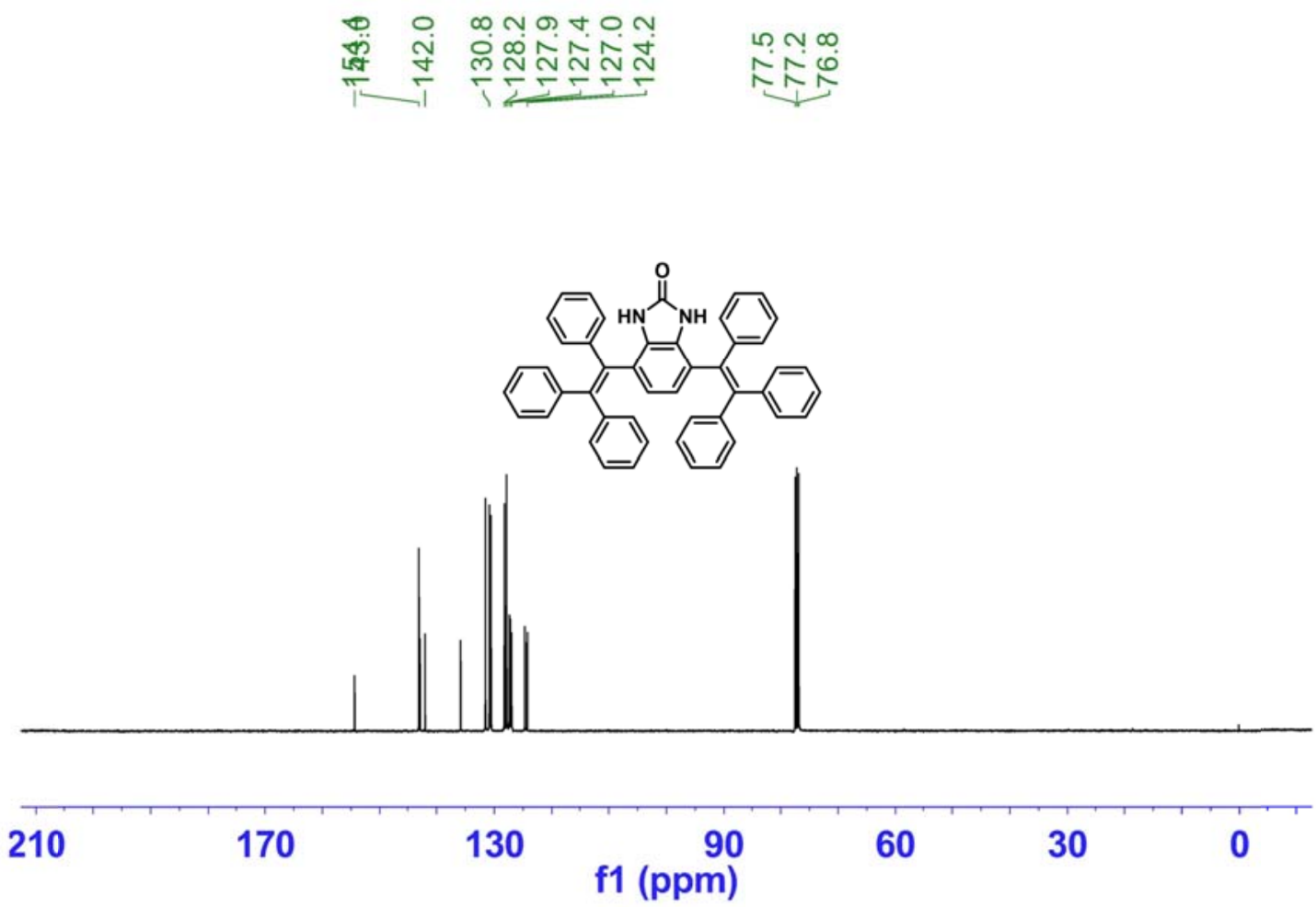

Figure S12. ${ }^{13} \mathrm{C}$ NMR spectra of compound IMTPE $\left(\mathrm{CDCl}_{3}, 101 \mathrm{MHz}\right)$. 


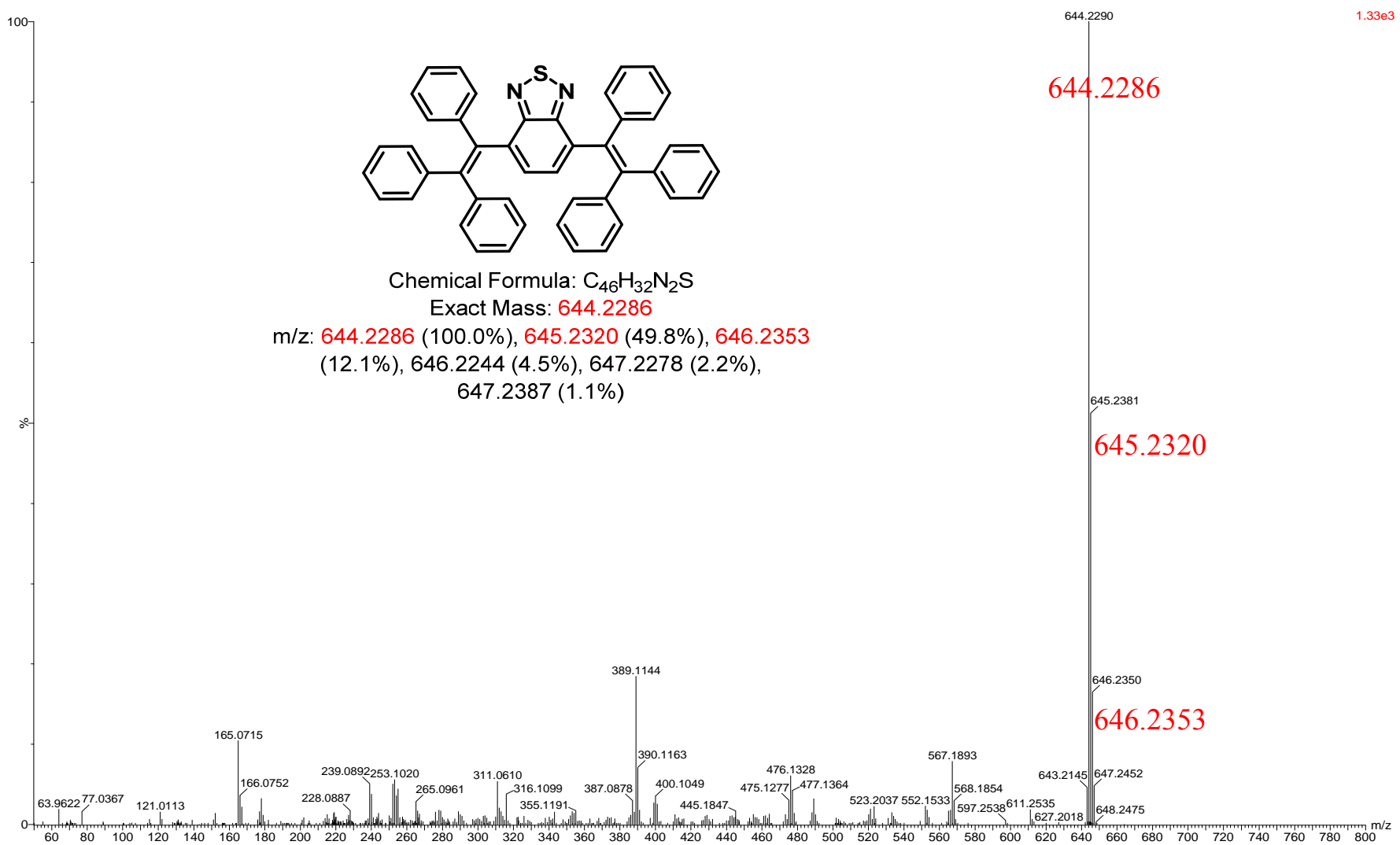

Figure S13. EI-MS spectra of compound 3.

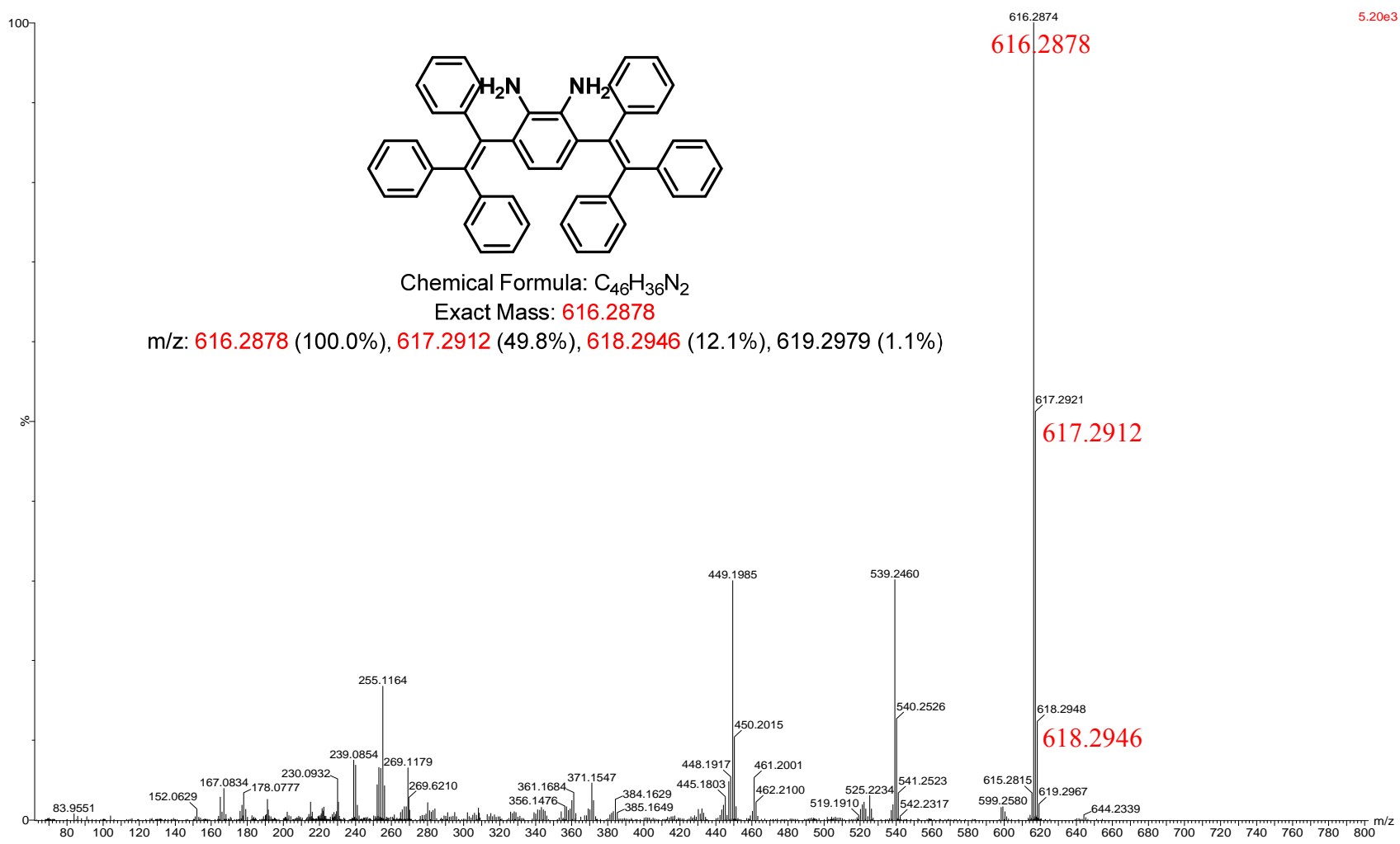

Figure S14. EI-MS spectra of compound DATPE. 


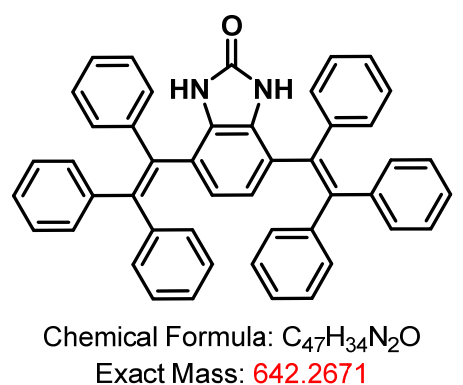

m/z: 642.2671 (100.0\%), 643.2705 (50.8\%), 644.2738 (12.6\%), 645.2772 (1.2\%)

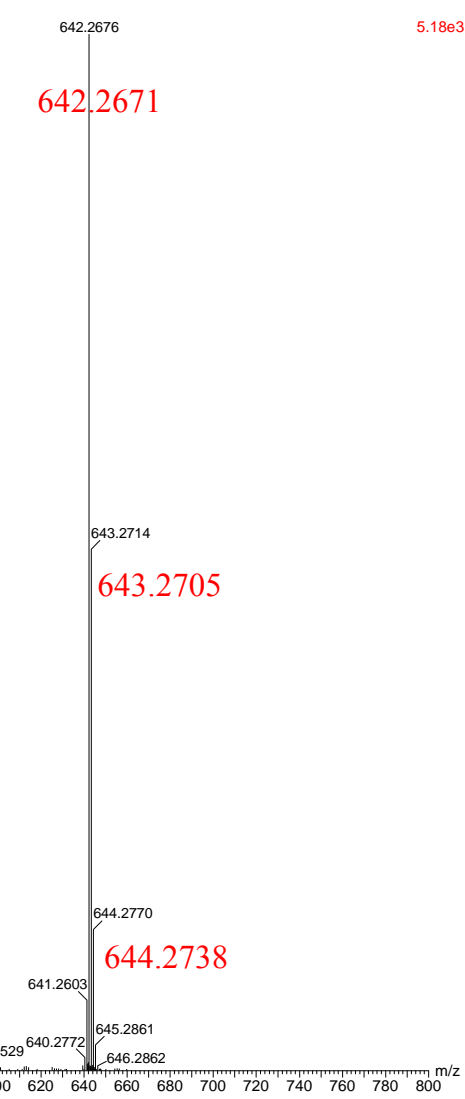

Figure S15. EI-MS spectra of compound IMTPE.

\section{References:}

[S1] Xie, H.; Wu, Y.; Zeng, F.; Chen, J.; Wu, S. An aie-based fluorescent test strip for the portable detection of gaseous phosgene. Chem. Commun. 2017, 53, 9813-9816.

[S2] Bai, L.; Feng, W.; Feng, G. An ultrasensitive fluorescent probe for phosgene detection in solution and in air. Dyes and Pigments 2019, 163, 483-488.

[S3] Kundu, P.; Hwang, K. C. Rational design of fluorescent phosgene sensors. Anal. Chem. 2012, 84, 4594-4597.

[S4] Wu, X.; Wu, Z.; Yang, Y.; Han, S. A highly sensitive fluorogenic chemodosimeter for rapid visual detection of phosgene. Chem. Commun. 2012, 48, 1895-1897.

[S5] Zhou, X.; Zeng, Y.; Chen, L.; Wu, X.; Yoon, J. A fluorescent sensor for dual-channel discrimination between phosgene and a nerve-gas mimic. Angew. Chem. Int. Ed. 2016, 55, 4729-4733.

[S6] Zhang, H.; Rudkevich, D. M. A fret approach to phosgene detection. Chem. Commun. 2007, 1238-1239.

[S7] Kim, T.-I.; Hwang, B.; Bouffard, J.; Kim, Y. Instantaneous colorimetric and fluorogenic detection of phosgene with a meso-oxime-bodipy. Anal. Chem. 2017, 89, 12837-12842. 
[S8] Chen, L.; Wu, D.; Kim, J.-M.; Yoon, J. An esipt-based fluorescence probe for colorimetric, ratiometric, and selective detection of phosgene in solutions and the gas phase. Anal. Chem. 2017, 89, 12596-12601.

[S9] Xia, H.-C.; Xu, X.-H.; Song, Q.-H. Fluorescent chemosensor for selective detection of phosgene in solutions and in gas phase. ACS Sens. 2017, 2, 178-182.

[S10] Hu, Y.; Zhou, X.; Jung, H.; Nam, S.-J.; Kim, M. H.; Yoon, J. Colorimetric and fluorescent detecting phosgene by a second-generation chemosensor. Anal. Chem. 2018, 90, 3382-3386.

[S11] Hu, Y.; Chen, L.; Jung, H.; Zeng, Y.; Lee, S.; Swamy, K. M. K.; Zhou, X.; Kim, M. H.; Yoon, J. Effective strategy for colorimetric and fluorescence sensing of phosgene based on small organic dyes and nanofiber platforms. ACS Appl. Mater. Interfaces 2016, 8, 22246-22252.

[S12] Du, M.; Huo, B.; Liu, J.; Li, M.; Shen, A.; Bai, X.; Lai, Y.; Fang, L.; Yang, Y. A turn-on fluorescent probe based on si-rhodamine for sensitive and selective detection of phosgene in solution and in the gas phase. J. Mater. Chem. C 2018, 6, 10472-10479.

[S13] Zhang, W.-Q.; Cheng, K.; Yang, X.; Li, Q.-Y.; Zhang, H.; Ma, Z.; Lu, H.; Wu, H.; Wang, X.-J. A benzothiadiazole-based fluorescent sensor for selective detection of oxalyl chloride and phosgene. Org. Chem. Front. 2017, 4, 1719-1725.

[S14] Feng, W.; Gong, S.; Zhou, E.; Yin, X.; Feng, G. Readily prepared iminocoumarin for rapid, colorimetric and ratiometric fluorescent detection of phosgene. Anal. Chim. Acta 2018, 1029, 97-103.

[S15] Liu, P.; Liu, N.; Liu, C.; Jia, Y.; Huang, L.; Zhou, G.; Li, C.; Wang, S. A colorimetric and ratiometric fluorescent probe with ultralow detection limit and high selectivity for phosgene sensing. Dyes and Pigments 2019, $163,489-495$.

[S16] Kim, T.-I.; Kim, D.; Bouffard, J.; Kim, Y. Rapid, specific, and ultrasensitive fluorogenic sensing of phosgene through an enhanced pet mechanism. Sens. Actuators B: Chem. 2019, 283, 458-462.

[S17] Sayar, M.; Karakuş, E.; Güner, T.; Yildiz, B.; Yildiz, U. H.; Emrullahoğlu, M. A bodipy-based fluorescent probe to visually detect phosgene: Toward the development of a handheld phosgene detector. Chem. Eur. J. 2018, $24,3136-3140$.

[S18] Xia, H.-C.; Xu, X.-H.; Song, Q.-H. Bodipy-based fluorescent sensor for the recognization of phosgene in solutions and in gas phase. Anal. Chem. 2017, 89, 4192-4197.

[S19] Zhang, Y.; Peng, A.; Jie, X.; Lv, Y.; Wang, X.; Tian, Z. A bodipy-based fluorescent probe for detection of subnanomolar phosgene with rapid response and high selectivity. ACS Appl. Mater. Interfaces 2017, 9, 13920-13927. 
[S20] Hu, Q.; Duan, C.; Wu, J.; Su, D.; Zeng, L.; Sheng, R. Colorimetric and ratiometric chemosensor for visual detection of gaseous phosgene based on anthracene carboxyimide membrane. Anal. Chem. 2018, 90, 8686-8691. [S21] Wang, S.-L.; Zhong, L.; Song, Q.-H. A ratiometric fluorescent chemosensor for selective and visual detection of phosgene in solutions and in the gas phase. Chem. Commun. 2017, 53, 1530-1533.

[S22] Maiti, K.; Ghosh, D.; Maiti, R.; Vyas, V.; Datta, P.; Mandal, D.; Maiti, D. K. Ratiometric chemodosimeter: An organic-nanofiber platform for sensing lethal phosgene gas. J. Mater. Chem. A 2019, 7, 1756-1767.

[S23] Wang, S.-L.; Zhong, L.; Song, Q.-H. Sensitive and selective detection of phosgene, diphosgene, and triphosgene by a 3,4-diaminonaphthalimide in solutions and the gas phase. Chem. Eur. J. 2018, 24, 5652-5658.

[S24] Wang, S.-L.; Zhang, C.-L.; Song, Q.-H. Selectively instant-response nanofibers with a fluorescent chemosensor toward phosgene in gas phase. J. Mater. Chem. C 2019, 7, 1510-1517. 